\title{
The effect of copper deficiency on reproduction in the female rat
}

\author{
By G. A. HALL AND J. McC. HOWELL \\ Department of Veterinary Pathology, University of Liverpool \\ (Received 25 April 1968-Accepted 20 September 1968)
}

\begin{abstract}
I. Eighty-seven rats were fed a diet of milk treated with hydrogen sulphide together with copper-free mineral and vitamin supplements. Forty-three of the eighty-seven rats were used as controls and given $\mathrm{Cu}$ supplements varying from 50 to $500 \mu \mathrm{g} / \mathrm{week}$. In addition to the eighty-seven rats, twenty-eight rats were fed a commercial diet.

2. Rats which did not receive $\mathrm{Cu}$ supplements developed signs of $\mathrm{Cu}$ deficiency and their liver $\mathrm{Cu}$ levels were significantly lower than those of control and stock animals. Oestrous cycles were normal and the majority of the rats were successfully mated.

3. Litters developed to full term in stock rats and in those given $\mathrm{Cu}$ supplements but the $\mathrm{Cu}$ deficient rats did not produce litters.
\end{abstract}

Copper deficiency has been associated with lowered fertility in cattle but the nature of the reproductive disturbance has not been determined (Underwood, 1962). Keil $\&$ Nelson (I93I) reported that female rats fed a diet of milk supplemented with ferric chloride only reproduced if copper sulphate was added. Dutt \& Mills (1960) recorded reproductive failure in female rats fed a $\mathrm{Cu}$-deficient diet. These rats had normal oestrous cycles and conceived but resorbed their foetuses. The experiments reported here confirmed and extended these findings.

\section{EXPERIMENTAL}

Animals and diet. Hooded, specific pathogen-free rats were used and at the start of the experiments they were from 9 to 12 weeks old. Stock rats were kept in conventional rat cages and fed Chardex GR 4 (Wyatt, Chard, Somerset) commercial rat diet with tap water ad lib. All other rats were kept in Perspex cages with Pyrex glass-rod bottoms modified from the design of McCosker (1967). These rats were given, from polythene bottles through Pyrex glass tubing, a diet of milk collected directly from the farm in polythene aspirators, and treated with hydrogen sulphide (Gallagher, Judah \& Rees, I956). They also received a vitamin and mineral supplement (Table $\mathrm{I}$ ). Rats fed on this diet alone will be called deficient rats. Control rats were given $\mathrm{Cu}$ as copper sulphate on 5 days of the week (Table 2). Rats receiving $100 \mu \mathrm{g}$ Cu were given their supplement from the feeding bottle before the milk was added; the other controls received to, 20 or $5^{\circ} \mu \mathrm{g} \mathrm{Cu}$ per os from a plastic syringe.

Experimental procedures. Vaginal smears were taken daily from each rat. Stock males were left overnight in the cage of females on heat and mating was considered to have taken place if a copulation plug was found or if numbers of sperm were seen in the vaginal smear. Twenty-eight of the deficient rats, all the rats receiving 10,20 and $50 \mu \mathrm{g}$ $\mathrm{Cu}$ and sixteen of the rats receiving $100 \mu \mathrm{g} \mathrm{Cu}$ were fed the diet for 4 weeks before 
the commencement of mating. Eight, eight and sixteen rats were fed the deficient diet for 2.5, 6 and 8 weeks respectively before mating, and twelve of the rats receiving roo $\mu \mathrm{g} \mathrm{Cu}$ were also fed the diet for 8 weeks before males were introduced.

Table 1. Composition of vitamin and mineral supplements

(A) Water-soluble vitamin and mineral supplement

Daily dose, given to each rat 5 days a week

$\begin{array}{ll}\text { Thiamine } & 0.050 \mathrm{mg} \\ \text { Pyridoxine } & 0.050 \mathrm{mg} \\ \text { Ribofiavine } & 0.10 \mathrm{mg} \\ p \text {-aminobenzoic acid } & 0.10 \mathrm{mg} \\ \text { Nicotinic acid } & 0.20 \mathrm{mg} \\ \text { Calcium pantothenate } & 0.80 \mathrm{mg} \\ \text { Folic acid } & 0.050 \mathrm{mg} \\ \text { Biotin } & 0.0050 \mathrm{mg} \\ \text { Inositol } & 4.0 \mathrm{mg} \\ \text { Vitamin } \mathrm{B}_{12} & 0.250 \mu \mathrm{g} \\ \text { MnSO } & .5 \mathrm{H}_{2} \mathrm{O}^{*} \\ \text { FeSO } & 2.1 \mathrm{mg} \\ \text { Choline chloride } & 1.3 \mathrm{mg} \\ & 10 \mathrm{mg}\end{array}$

(B) Oil-soluble vitamin supplement

$\begin{array}{cc} & \begin{array}{c}\text { Dose given to each } \\ \text { rat twice weekly in } \\ 0.5 \mathrm{ml} \text { arachis oil } \\ \text { Vitamin A acetate }\end{array} \\ \begin{array}{cc}0.03740 \mathrm{mg} \\ \text { DL- } \alpha \text {-tocopheryl } \\ \text { acetate }\end{array} & \begin{array}{c}\text { Either } 1.2 \mathrm{mg} \text { or } \\ 10.0 \mathrm{mg} \dagger\end{array}\end{array}$

* Specpure (Johnson Matthey Chemicals Ltd, 73-83 Hatton Garden, London, ECI).

+ The lower level of tocopheryl acetate was given to twenty of the twenty-eight deficient rats mated at 4 weeks, to sixteen of the deficient rats mated at 8 weeks, and to all the rats receiving the $100 \mu \mathrm{g} \mathrm{Cu}$ supplement. All the remaining rats received the io $\mathrm{mg}$ level.

Precautions taken to avoid contamination by extraneous $\mathrm{Cu}$. The cages, feeding pots and other utensils were washed in a detergent, left standing for at least $12 \mathrm{~h}$ in $0 \cdot \mathrm{I}$ M-disodium ethylenediamine tetra-acetic acid, rinsed in a tank of deionized water and washed in running deionized water before they were reassembled. Rats fed the milk diet were handled only with rubber gloves washed in deionized water. They were weighed in polythene bags which had been washed in deionized water and were transferred to clean cages once a week. Wood wool which had been washed in deionized water and dried was provided as nesting material for rats with young. All storage vessels were of Pyrex glass (see Butler \& Newman, 1956).

Examinations at the end of the experiments. Rats were killed by ether inhalation and exsanguinated. The animals were examined for changes in the colour of coat and teeth. Tissues for $\mathrm{Cu}$ analysis were removed using stainless steel instruments washed in deionized water and were kept at $-20^{\circ}$ in chemically clean polystyrene pots. The $\mathrm{Cu}$ levels were determined by a modification of the method of Eden \& Green (I940). 


\section{RESULTS}

Reproduction. Details of the rats used and the results of the matings are given in Tables 2 and 3. Oestrous cycles were normal until mating and in the deficient group many rats recommenced oestrous cycles after an interrupted pregnancy (Table 4 )

Table 2. Summary of breeding records of copper-deficient, Cu-supplemented and stock rats

\begin{tabular}{|c|c|c|c|c|c|c|}
\hline Type of diet & $\begin{array}{c}\text { Cu supple- } \\
\text { ment as } \mu \mathrm{g} \\
\mathrm{Cu} \text { given on } \\
5 \text { days of } \\
\text { the week }\end{array}$ & $\begin{array}{l}\text { No. of } \\
\text { rats }\end{array}$ & $\begin{array}{c}\text { No. not } \\
\text { mated }\end{array}$ & $\begin{array}{c}\text { No. of } \\
\text { matings }\end{array}$ & $\begin{array}{l}\text { No. not } \\
\text { producing } \\
\text { full-term } \\
\text { pups }\end{array}$ & $\begin{array}{l}\text { No. } \\
\text { producing } \\
\text { full-term } \\
\text { pups }\end{array}$ \\
\hline Milk treated & o & 44 & 8 & 40 & 40 & 0 \\
\hline with & 10 & 8 & 2 & 7 & 6 & I \\
\hline hydrogen & 20 & 8 & I & 8 & 4 & 4 \\
\hline \multirow[t]{2}{*}{ sulphide } & 50 & 7 & o & 8 & I & 7 \\
\hline & 100 & 20 & 3 & 20 & 5 & 15 \\
\hline Stock & o & 28 & 4 & 32 & 8 & 24 \\
\hline
\end{tabular}

Table 3. Details of the successful matings of control rats shown in the last line of Table 2

Cu supplement as $\mu \mathrm{g} \mathrm{Cu}$ given on 5 days of the week

$\begin{array}{cc}\text { No. of } & \text { No. of fertile } \\ \text { matings } & \text { matings }\end{array}$

7

8

8

20

I 5
I

4

7

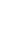$$
4
$$

$$
\text { No. of fertile }
$$

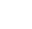


and continued until they were killed at the end of the experiments. All groups mated well including the deficient group and the group supplemented with $100 \mu \mathrm{g} \mathrm{Cu}$ that were fed the diet for 8 weeks before males were introduced.

There were thirty-two matings in the stock rats and twenty-four produced fullterm pups. A total of eighty-three matings occurred in the milk-fed rats and twentyseven produced full-term pups, all of these were in the $\mathrm{Cu}$-supplemented groups (Table 2) and some of their pups were successfully weaned and used in other experiments which will be reported elsewhere. The results of the productive matings in the $\mathrm{Cu}$-supplemented groups are given in Table 3 .

Table 4. Details of vaginal bleeding and recurrence of oestrous cycles in rats that did not produce pups in the deficient group, and in those supplemented with $10 \mu \mathrm{g}$ and $20 \mu \mathrm{g} \mathrm{Cu}$

Day on
which
bleeding
first
seen
9
I0
I I
I 2
I3
I4
I5
I6

$\begin{array}{ccc}\begin{array}{c}\text { No. in which } \\ \text { oestrous } \\ \text { cycles re- }\end{array} & \begin{array}{c}\text { Day after } \\ \text { mating of } \\ \text { recommence- } \\ \text { bleeding } \\ \text { commenced }\end{array} \\ 4 & \text { I } & \text { Blent of oestrus } \\ 5 & 2 & 9 \\ 6 & 3 & 12,13 \\ 5 & 1 & 14,15,20 \\ 3 & 2 & 27 \\ 1 & 1 & 14, \text { I } 5 \\ 0 & - & 16 \\ 0 & - & -\end{array}$

\begin{tabular}{|c|c|c|}
\hline \multicolumn{3}{|c|}{ Bleeding for more than 3 days } \\
\hline $\begin{array}{l}\text { No. } \\
\text { bleeding }\end{array}$ & $\begin{array}{l}\text { No. in which } \\
\text { oestrous } \\
\text { cycles re- } \\
\text { commenced }\end{array}$ & $\begin{array}{c}\text { Day after } \\
\text { mating of } \\
\text { recommencement } \\
\text { of oestrus }\end{array}$ \\
\hline 0 & 一 & - \\
\hline o & - & $\longrightarrow$ \\
\hline 2 & o & 0 \\
\hline 0 & - & 一 \\
\hline $\mathbf{I}$ & I & $2 I$ \\
\hline 10 & 6 & $20,2 I, 2 I, 2 I, 2 I, 23$ \\
\hline 4 & 3 & $21,22,23$ \\
\hline 2 & 2 & 20,22 \\
\hline
\end{tabular}

Litters were not born to rats fed the diet without a $\mathrm{Cu}$ supplement (Table 2). A total of fifty-six rats fed the milk diet did not produce full-term pups (Table 2). Subsequent to mating, forty-three of these bled from the vagina and in a number of them oestrous cycles recommenced. These rats were in the deficient, Io and $20 \mu \mathrm{g} \mathrm{Cu}-$ supplemented groups and could be divided into two types. In one vaginal bleeding occurred early, was of short duration and oestrous cycles usually recommenced within a short time. In the other, vaginal bleeding was prolonged and oestrous cycles did not recur for several days. The details are given in Table 4 . Four of the deficient rats that bled early for a short time and immediately recommenced oestrous cycles were killed and their uteri were found to be non-gravid.

Evidence of $\mathrm{Cu}$ deficiency. The deficient rats which had been fed the diet for 12 or more weeks had grey-coloured head markings and their incisor teeth were depigmented. The control rats did not show these changes. The $\mathrm{Cu}$ levels in the liver of unmated female stock, Cu-deficient and control rats fed at the roo $\mu \mathrm{g}$ level for $\mathrm{I} 2$ weeks were, respectively, $14 \cdot 43 \pm 0.397, \mathrm{I}^{\circ} 34 \pm 0.523$ and $10.84 \pm 0.85^{8} \mathrm{ppm}$ dry weight.

\section{DISCUSSION}

These results clearly indicate that $\mathrm{Cu}$ is essential for the maintenance of pregnancy in the rat (Tables 2 and 3 ) and confirm the results of Keil \& Nelson (1931) and Dutt $\&$ Mills (1960). Pups were borne by rats which had received five daily doses of $20 \mu \mathrm{g}$ 
$\mathrm{Cu} /$ week but the pups died within a short time of birth. Pups were born from and weaned by rats which had received five daily doses of $5 \circ \mu \mathrm{g} \mathrm{Cu} /$ week. This level of $\mathrm{Cu}$ supplementation supported pregnancy and lactation.

Forty-three of the rats which did not produce full-term pups bled from the vagina after mating (Table 4). The rats which showed vaginal bleeding for several days and were slow to recommence cycling, or which never cycled again, were considered to be resorbing their foetuses in the manner described by Howell \& Hall (I969). This is supported by the fact that over half of them were first seen to bleed on the I4th day of pregnancy, which is a critical time in the resorptive process (Howell \& Hall, I969). In many of the rats which bled for a short time and never recycled, or which did so after several days, resorption of the foetuses may have been taking place.

A group of eight rats bled for a short time and oestrous cycles commenced almost immediately. It is most unlikely that resorption of the foetuses was taking place in these rats. Four were killed and their uteri were non-gravid. This phenomenon was not seen in the rats in other groups nor is it recorded as an event in pseudopregnancy (Long \& Evans, I922). To test this we vasectomized six male rats and mated them to twelve females fed a stock diet. The post-mating vaginal smears of these rats were typical of pseudopregnancy (Long \& Evans, 1922), and they did not show vaginal bleeding. The mechanisms involved in this phenomenon are not understood.

We wish to thank Professor D. L. Hughes for advice and encouragement; Mrs M. W. Harling, AIMLT, Miss A. Ronald and Mrs C. Savage for technical assistance, and Mr G. Weston, FIMLT and Mr E. O'Neill for the photographs. G. A. H. was an Agricultural Research Council postgraduate research student. The work was supported by a grant from the Agricultural Research Council.

\section{REFERENCES}

Butler, E. J. \& Newman, G. E. (1956). F. clin. Path. 9, 157.

Dutt, B. \& Mills, C. F. (1960). \%. comp. Path. 70, 120.

Eden, A. \& Green, H. H. (I940). Biochem. F. 34, I 202.

Gallagher, C. H., Judah, J. D. \& Rees, K. R. (I956). Proc. R. Soc. B I45, I34.

Howell, J. McC. \& Hall, G. A. (I969). Br. F. Nutr. 23, 47.

Keil, H. L. \& Nelson, V. E. (I93I). F. biol. Chem. 93, 49.

Long, J. A., \& Evans, H. M. (1922). Mem. Univ. Calif. 6 I.

McCosker, P. J. (1967). Br. F. Nutr. 21, 231.

Underwood, E. J. (1962). Trace Elements in Human and Animal Nutrition, 2nd ed. New York and London: Academic Press Inc. 